\title{
Florida State Symbols ${ }^{1}$
}

Martin B. Main and Ginger M. Allen²

\section{Introduction}

Florida has a diversity of habitats that support a rich flora and fauna. Ponce DeLeon, who explored Florida in 1513 in search of the mythical "Fountain of Youth," recognized Florida for its beauty.

DeLeon claimed Florida for Spain and named this new land "Pascua de Florida," which translates as "feast of flowers." Florida was sold to the United States in 1819 and became the 27th state of the United States on March 3, 1845.

Today, Florida is known as the Sunshine State. The state capitol resides in Tallahassee. In honor of Florida's natural resources, state legislators have identified several state symbols.

\section{Florida State Animal}

Florida Panther (Puma concolor coryi)

Size: males—about 7 feet, $85-155$ pounds; females-about 6 feet, 50-100 pounds

Range: south Florida

Habitat: forested wilderness, cypress swamps

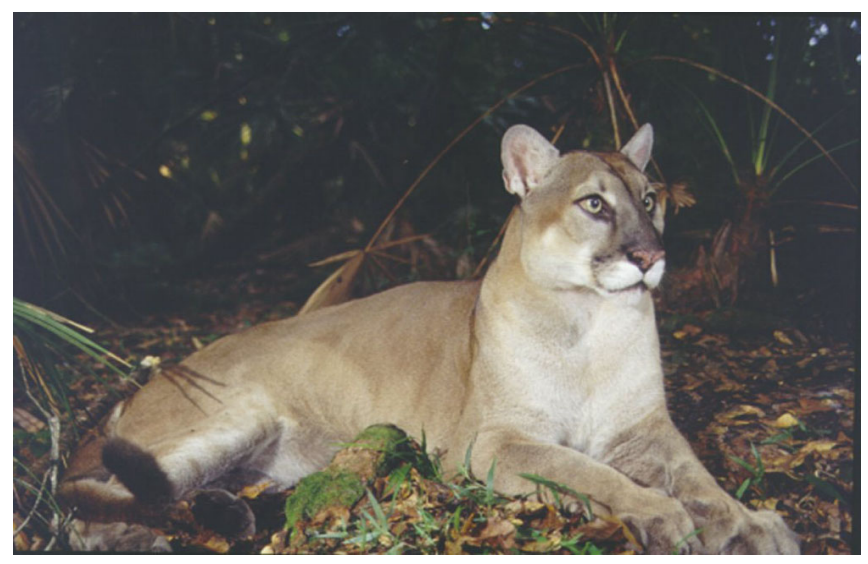

Figure 1. Florida panther. Credits: Larry Richardson

Fun Facts:

- home range size averages 75 square miles for females, 200 sq. mi. for males

- females give birth to 1-5 kittens that stay with the mother for $1-2$ years

- listed as state and federally endangered

In 1982, students throughout Florida chose the Florida panther over the manatee, alligator, and Florida Key deer to be designated as the Florida state animal. With numbers estimated at less than 100 animals, the panther is one of Florida's most

1. This document is Circular 1467, one of a series of the Department of Wildlife Ecology \& Conservation, Florida Cooperative Extension Service, Institute of Food and Agricultural Sciences, University of Florida. Publication Date: May 2005. Please visit the EDIS Web site at http://edis.ifas.ufl.edu.

2. Martin B. Main, associate professor and wildlife extension specialist, and Ginger M. Allen, senior biologist, Department of Wildlife Ecology and Conservation, University of Florida/IFAS, Gainesville, FL.

The Institute of Food and Agricultural Sciences (IFAS) is an Equal Opportunity Institution authorized to provide research, educational information and other services only to individuals and institutions that function with non-discrimination with respect to race, creed, color, religion, age, disability, sex, sexual orientation, marital status, national origin, political opinions or affiliations. U.S. Department of Agriculture, Cooperative Extension Service, University of Florida, IFAS, Florida A. \& M. University Cooperative Extension Program, and Boards of County Commissioners Cooperating. Larry Arrington, Dean 
endangered species. A relative of the western cougar, the Florida panther needs vast tracks of wild lands to survive. Unfortunately, Florida's rapidly expanding population is continually pushing development farther into panther territory. Despite increased awareness and concern, continued loss of habitat paints a bleak future for the Florida panther.

\section{Florida State Marine Mammal}

West Indian Manatee (Trichechus manatus latirostris)

Size: up to 13 feet long and 3,000 pounds

Range: concentrated in Florida. In summer, sparsely found in Alabama, Virginia, and the Carolinas

Habitat: rivers, canals, estuaries, saltwater bays

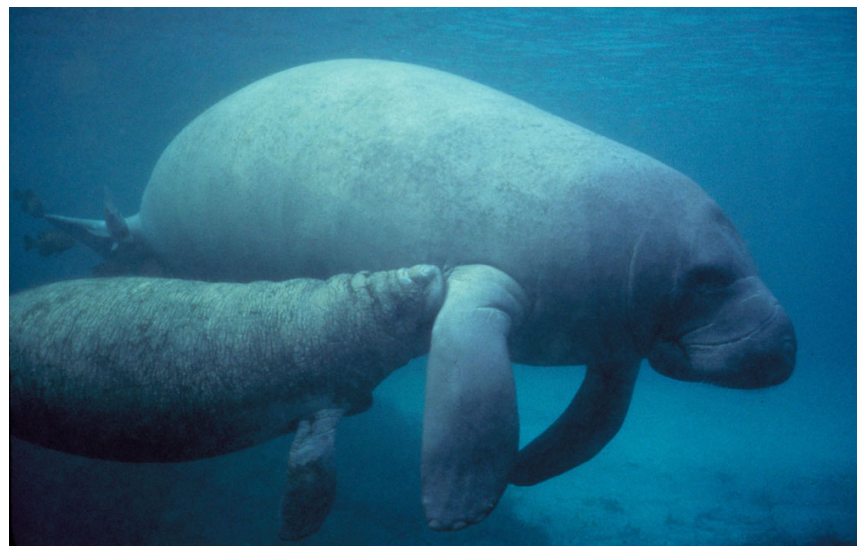

Figure 2. Florida manatee. Credits: U.S.F.W.S.

\section{Fun Facts:}

- eats 60-100 pounds of aquatic vegetation each day

- sleep on the bottom; surface every 5-20 minutes to breathe

- related to elephants, hyraxes, and aardvarks

In 1975, the legislature designated the West Indian manatee the state marine mammal. Although the name has at times caused confusion, the West Indian manatee is native to Florida as well as the West Indies (Caribbean Islands) and portions of Central and South America. The manatee is a large, slow-moving mammal that lives in Florida's coastal estuaries and rivers, where it eats massive quantities of aquatic plants. These gentle giants must surface for air approximately every five minutes, which puts them in danger of collision with motorboats. Approximately 25 percent of all recorded manatee deaths are caused by motorboats, and many more animals are injured each year. Slow speed zones have been implemented in many Florida waterways in an effort to protect manatees. In 1973, the manatee was added to the endangered species list. Today, manatees are estimated to number 2,500-3,500 animals in Florida.

\section{Florida State Saltwater Mammal}

\section{Bottlenose Dolphin (Tursiops truncatus)}

Size: adult 6-9 feet, 330-440 pounds

Range: ocean/seas throughout the world

Habitat: brackish waters, river mouths, oceans, bays, estuaries

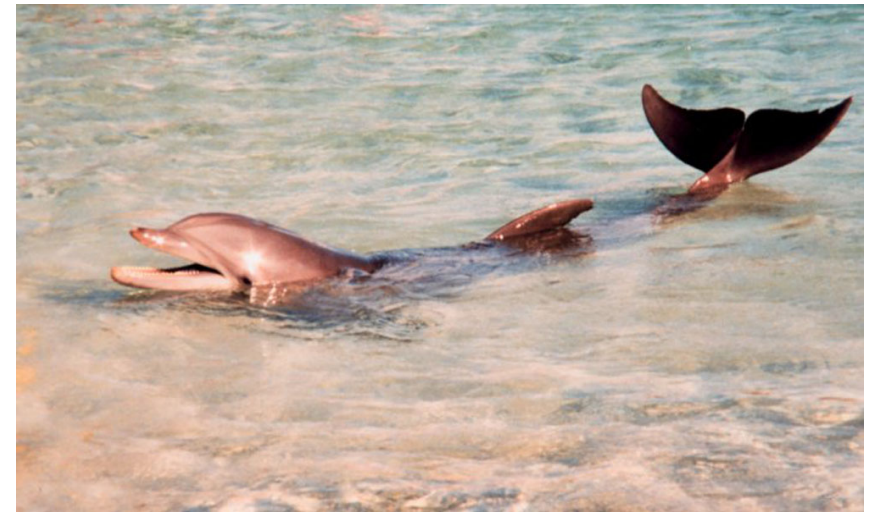

Figure 3. Bottlenose dolphin. Credits: NOAA

Fun Facts:

- live in family groups known as "pods" (2-15); multiple pods form herds

- reproduce one offspring every 2-3 years

- interact with humans in the wild

- use echolocation to find prey

The 1975 Florida Legislature designated the "porpoise" as the official Florida saltwater mammal, which is a term that is sometimes used to describe the bottlenose dolphin. Although porpoises 
and dolphins are related (Order Cetacea), there are no true porpoises found in Florida waters. Bottlenose dolphins are frequently observed in Florida's coastal waters and are known for their playfulness, often racing abreast or in the wake of motorboats. Typical dolphin antics include breaching and midair twists. Historically, sailors have considered the presence of dolphins as a sign of good luck.

\section{Florida State Saltwater Fish}

\section{Sailfish (Istiophorus platypterus)}

Size: Atlantic variety - up to 11 feet, 25-50 pounds

Range: worldwide; Atlantic and gulf of Mexico coasts

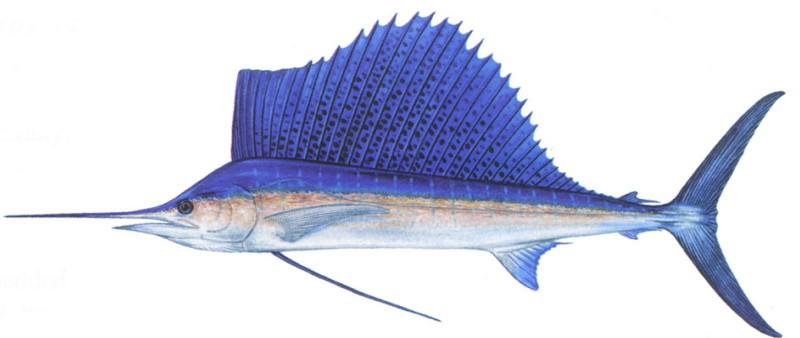

Figure 4. Sailfish. Credits: Diane Peebles

\section{Fun Facts:}

- typically live about 5 years

- groups of sailfish raise sails to corral schooling fish

- can swim $68 \mathrm{mph}$, faster than marlin

The sailfish is a popular saltwater game fish in Florida's offshore waters. It is named for its large, sail-like dorsal fin that is raised when the fish is excited or comes to the surface. Sailfish are brilliantly colored with dark, iridescent blue on top, silver on the belly, and purple stripes on the back. The sailfish often travels and feeds in schools. The sailfish is known among fisherman for its fighting ability and tendency to leap out of the water. In recent years, sailfish populations have declined from overfishing, and anglers are encouraged to catch and release this beautiful state fish.

\section{Florida State Freshwater Fish}

Florida Largemouth Bass (Micropterus salmoides floridanus)

Size: maximum length 3 feet, averages 4-8 pounds

Range: Florida, introduced in other states

Habitat: prefers warm, slow-moving water

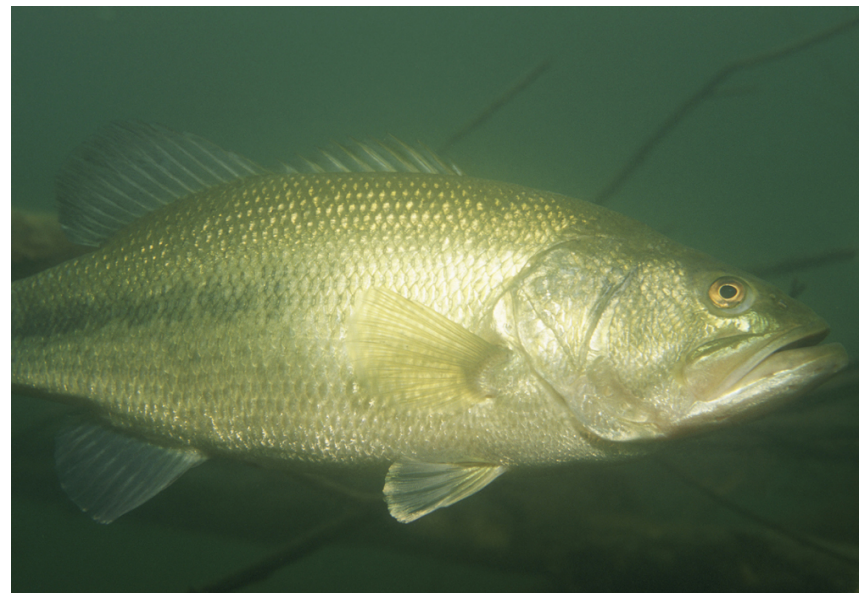

Figure 5. Florida largemouth bass. Credits: U.S.F.W.S.

\section{Fun Facts:}

- Florida's official largemouth bass record is 17.27 pounds

- the world-record bass weighed 22 pounds, 4 ounces and was caught near Jacksonville, Georgia, on June 21932

In addition to a state saltwater fish, Florida has designated the largemouth bass as the state freshwater fish. Florida is the only state to have two official state fish symbols. The largemouth bass may well be the most popular freshwater game fish in the United States. Largemouth bass are native to or stocked in freshwater ponds, lakes, and rivers in nearly every state. The Florida largemouth bass is a subspecies of the northern largemouth and is known to grow faster than northern races. Although Florida largemouth bass were originally found only in Florida, they have been stocked in several other states, including Texas and California. 


\section{Florida State Reptile}

American Alligator (Alligator mississippiensis)

Size: adult female - averages 8 feet, 160 pounds; adult male - averages 11 feet 400 pounds

Range: North Carolina to Florida; west to central Texas

Habitat: swamps, deep marshes, lakes, ponds, rivers, canals

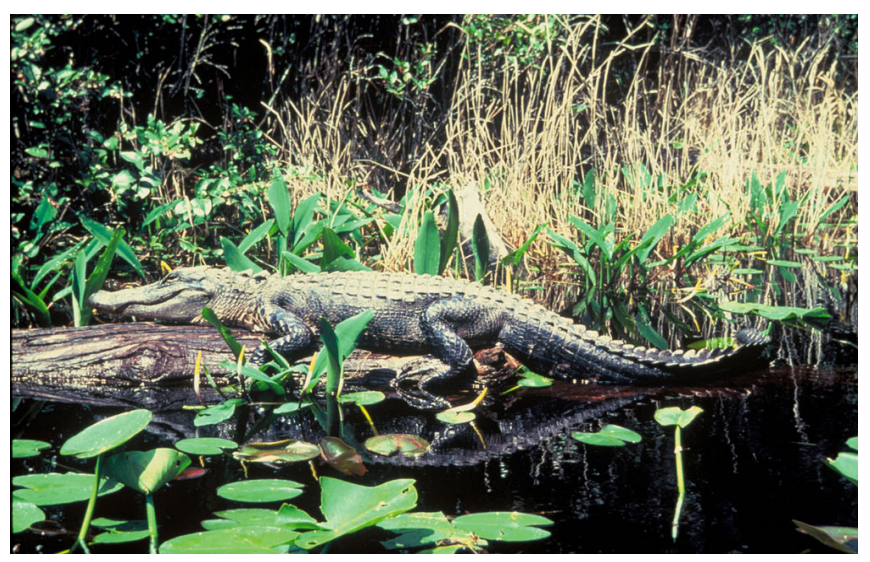

Figure 6. American alligator. Credits: U.S.F.W.S.

Fun Facts:

- largest record alligator from Florida measured 19 feet long

- alligators lose and replace 2,000-3,000 teeth in a lifetime

- alligators wallow out deep holes in wetlands that create important habitat for other animals

In 1987, the American alligator was designated the official Florida state reptile. Alligators occur in freshwater ponds, lakes, and rivers throughout Florida and are characterized by broad, rounded snouts and dark color. Florida crocodiles occur in marine and estuarine waters of extreme south Florida and have light coloration, narrow snouts, and protruding teeth. Alligators were hunted nearly to extinction and were listed as an endangered species in 1967. Alligator populations recovered and are plentiful in Florida today. Increased numbers of alligators and a growing human population in the state increase risks of alligator-human conflicts. This is particularly true for alligators that are fed because they lose their fear of humans, which increases the risk of an alligator attack. It not only is dangerous but illegal to feed alligators in Florida.

\section{Florida State Shell}

\section{Horse Conch (Pleuroploca gigantea)}

Size: $4-24$ inches long

Range: North Carolina to Florida and Texas

Habitat: sandy, shallow near shore marine waters

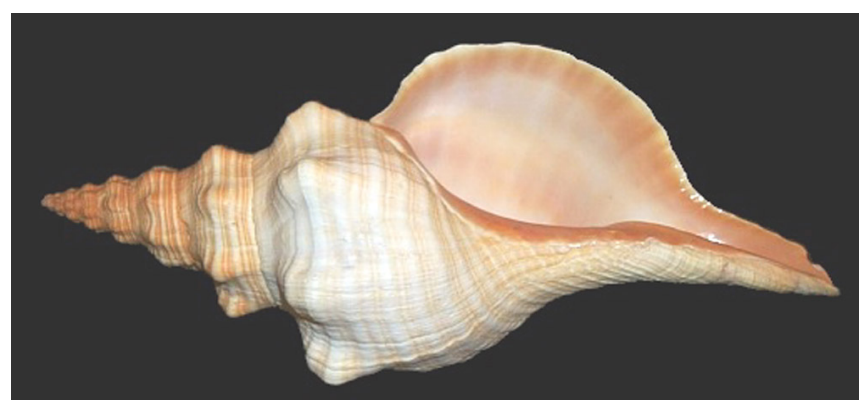

Figure 7. Horse conch. Credits: Jacksonville Shell Club

\section{Fun Facts:}

- largest marine snail in Florida waters

- predatory; grabs other snails and inserts toothed tongue to devour soft flesh

The horse conch, also known as the giant band shell, was designated Florida's state shell in 1967. The horse conch is native to marine waters surrounding Florida. It is the largest snail (shell) found in Florida's coastal waters and one of the largest in the world. It is often found in sea grass meadows, where it hunts other snails.

\section{Florida State Bird}

\section{Northern Mockingbird (Mimus polyglottos)}

Size: $9-11$ inches

Range: southern Canada to southern Mexico, West Indies and introduced in Hawaii

Habitat: Urban areas, farms, roadsides, dense thickets 


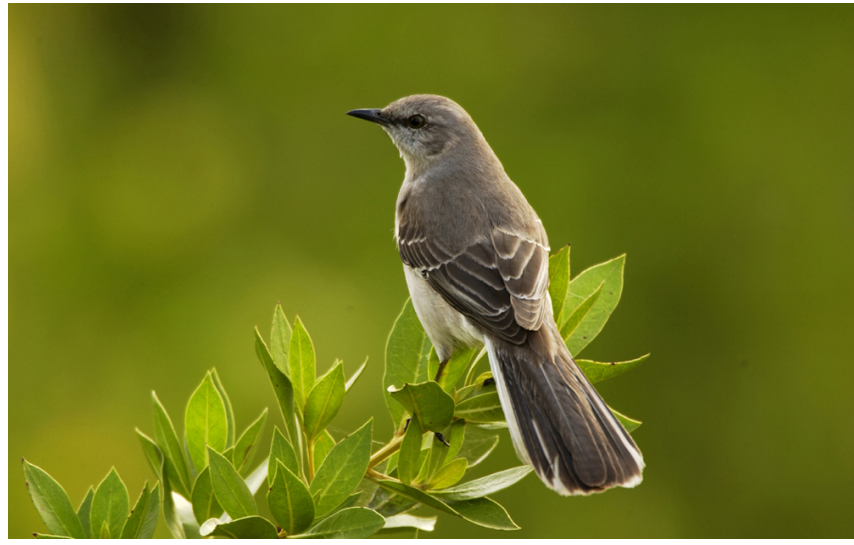

Figure 8. Northern mockingbird. Credits: U.S.F.W.S.

\section{Fun Facts:}

- range is expanding northward

- Mockingbirds attack other birds during nesting season

- known for singing and ability to mimic other birds

In 1927, the Mockingbird was designated as the Florida state bird. The Mockingbird is gray with large white patches on its wings and tail and is noted for its singing ability. Mockingbirds may sing for hours and sing throughout the year to defend their feeding territories. In particular, the Mockingbird is unique for its ability to mimic the songs and calls of other birds. It is believed that the Mockingbird can mimic at least 30 species of birds as well as other sounds, such as barking dogs. The Mockingbird is the state bird in four other states. Attempts have been made to change the Florida state bird to the Florida Scrub Jay, but these have been unsuccessful to date.

\section{Florida State Insect}

\section{Zebra Butterfly (Heliconius charitonius)}

Size: $3-4$ inches

Range: somewhat rare throughout southern United States coastal plain

Habitat: hammocks, swamps, forests

\section{Fun Facts:}

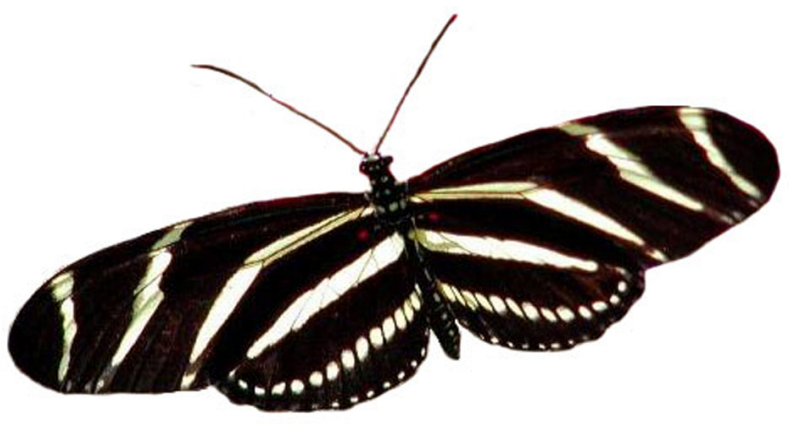

Figure 9. Zebra Butterfly. Credits: UF/IFAS

- sleep in groups and return to the same roost every night

- older butterflies seem to have first choice at sleeping perches

- at dawn, the first butterfly to awaken rouses the others by gently touching them

Florida's newest state symbol was designated in 1996 at the request of garden clubs across the state. The zebra butterfly (previously called zebra longwing) has elongated, black wings with yellow stripes and long antennae. The butterfly's distinctive pattern resembles shadows and light filtering through the forest canopy. The bold pattern is also believed to serve as warning to predators of the butterfly's nauseating taste, which comes from toxins obtained from eating plants in the passion vine family. Zebra butterflies are unusual in that they cluster at night and sleep in groups, returning repeatedly to the same roost.

\section{Florida State Tree}

\section{Sabal Palm (Sabal palmetto)}

Size: leaf blades - 3-4 feet; height - up to 90 feet

Range: North Carolina to Florida

Habitat: wet to dry hammocks/prairies, urban areas, coastal areas.

\section{Fun Facts:}

- berries eaten by wildlife

- Seminoles used berries in medicinal remedies 


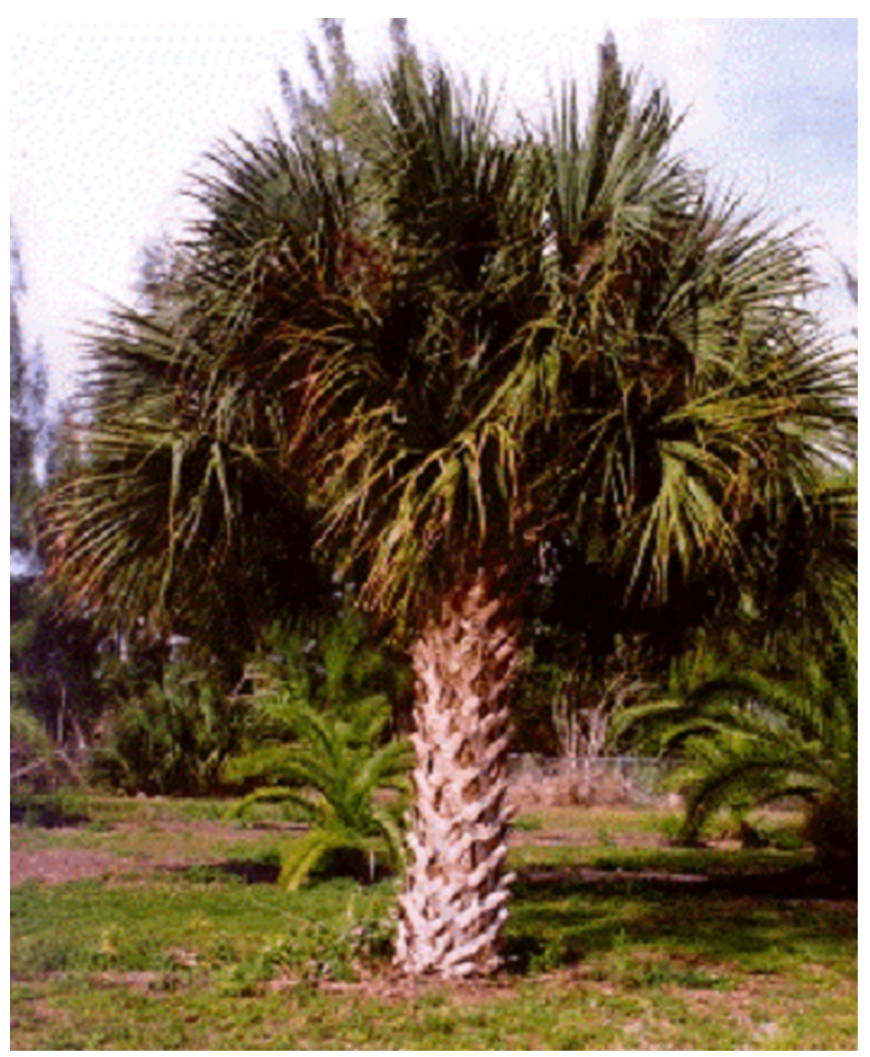

Figure 10. Sabal palm. Credits: UF/IFAS

- old leaf stalks on trunks (bootjacks) provide habitat for small animals

The sabal palm, also known as the cabbage palm, was designated the state tree in 1953 and occurs on the Florida state seal. Designation as the state tree followed years of debate that considered the royal palm, slash pine, and longleaf pine as other options. Oddly enough, the sabal palm is not a true tree and, as a palm, is more closely related to grasses. Early Floridians had a variety of uses for the sabal palm. The bud of the tree is edible and is known as heart of palm and swamp cabbage; the trunk and fronds were used to build shelter; and various fibrous parts were used to make cordage.

\section{Florida State Wildflower}

\section{Coreopsis (Coreopsis species)}

Size: $1-3$ feet

Range: most of United States

Habitat: wet to dry soils

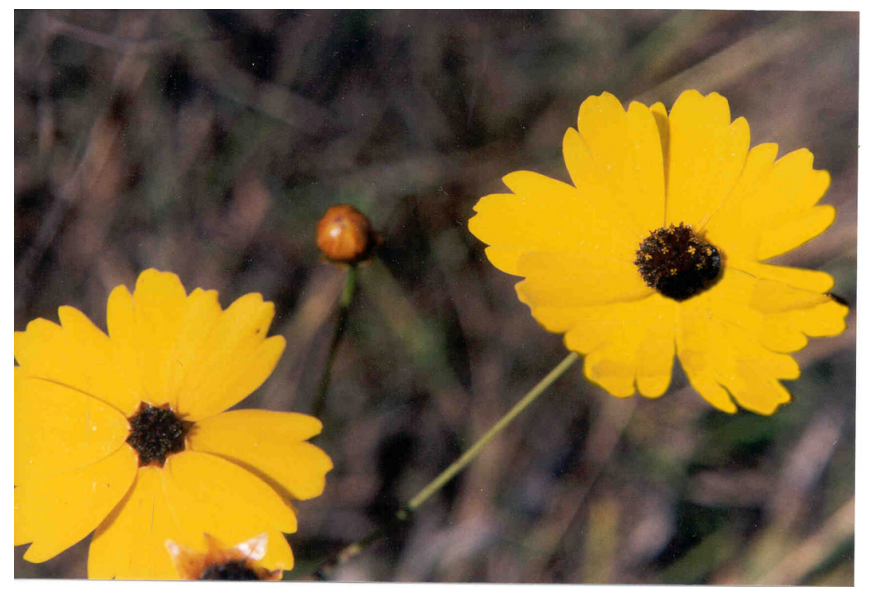

Figure 11. Coreopsis. Credits: UF/IFAS

\section{Fun Facts:}

- flower heads provide food source for seed-eating birds

- sometimes called tickseed, as disc flowers look like small bugs

In 1991, all flowers in the Coreopsis genus were designated as the Florida state wildflower. Thirteen species of Coreopsis occur in Florida, 12 of which are native, including one that is endangered (Coreopsis integrifolia). The Coreopsis flowers occur in a variety of colors ranging from yellow to pink and are used extensively in roadside beautification programs.

\section{Florida State Flower}

\section{Orange (Citrus species)}

Size: average tree height 12 feet

Range: mainly central and south Florida

Habitat: wild species found in hammocks

\section{Fun Facts:}

- Florida produces the majority of oranges grown in the United States

- 90-95 percent of the Florida orange crop is processed for juice

- Orange blossoms are used in tea and bakery products 


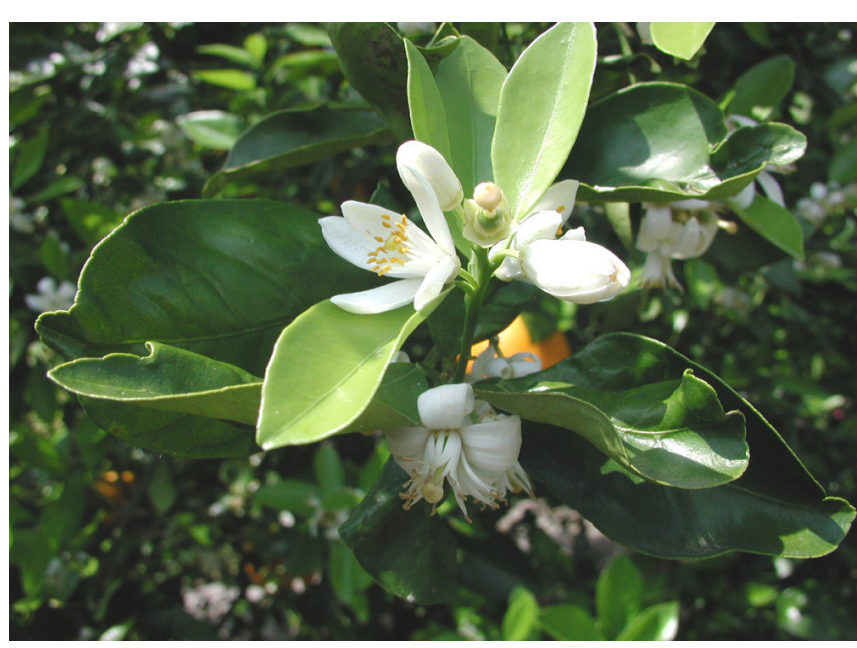

Figure 12. Orange blossom. Credits: UF/IFAS

- most of Florida's honey is produced from bees that gather orange blossom nectar

The orange blossom was Florida's original state flower and was designated as such in 1909. Because the orange tree is not native to Florida, the Coreopsis was added as the state wildflower in 1991. Florida's citrus industry developed from 16th century Spanish introductions that grew well and became established in Florida's warm climate. Indians and pioneers transplanted citrus trees throughout the warmer parts of the state. During the 1830s, commercial citrus trees were grafted on sour orange rootstock to improve disease resistance and create a commercial market. Florida quickly became known for its oranges, and orange juice was named the state beverage of Florida in 1967. Today, the Florida citrus industry has an annual economic impact estimated at $\$ 9$ billion.

\section{Other Florida State Symbols}

- State Song: "The Swanee River" ("Old Folks at Home"); written by Stephen C. Foster

- State Gem: Moonstone

- State Stone: Agatized coral

- State Soil: Myakka fine sand

- State Beverage: Orange juice

\section{Additional Information}

Florida Department of Agriculture and Consumer Services: http://www.doacs.state.fl.us.

Florida Office of Cultural and Historical Programs, State Symbols: http://dhr.dos.state.fl.us/facts/symbols/.

Froese, R. and D. Pauly. Editors. 2004. FishBase. World Wide Web electronic publication: http://www.fishbase.org.

Gilman, E.F. and D.G. Watson, 1993. Sabal Palmetto: Cabbage Palm. Fact Sheet ENH-733, University of Florida/IFAS: http://edis.ifas.ufl.edu/ST575.

Richardson, L.W., and M.B. Main, 2001. Did I See a Panther? Fact Sheet WEC 145, University of Florida/IFAS: http://edis.ifas.ufl.edu/UW144.

Sprott, P. and F.J. Mazzotti, 2001. Mockingbirds (Mimus polyglottos) Fact Sheet SS-WIS-46, University of Florida/IFAS: http://edis.ifas.ufl.edu/UW094.

Stephens, J.M., 1994. Swamp Cabbage. Fact Sheet HS-571, University of Florida/IFAS: http://edis.ifas.ufl.edu/MV038.

Alligators and Crocodiles, 1998. Fact Sheet WEC-QRS-003, University of Florida/IFAS, Department of Wildlife Ecology and Conservation: http://edis.ifas.ufl.edu/UW003.

USDA, Florida Agricultural Statistics Service: http://www.nass.usda.gov/fl.

Wunderlin, R. P., and B. F. Hansen. 2004. Atlas of Florida Vascular Plants, Institute for Systematic Botany, University of South Florida, Tampa: www.plantatlas.usf.edu. 